loveable term in medicine. To this, the authors quote from E Fuller Torrey (6) that "Prevention is powerful, efficient, and American"!

Nevertheless, we feel that there is room for disagreement with some of the premises of the authors. For example, readers may remain confused about the benefits of "the juice of sweet gourd (dudhi)" as proposed by the authors. They certainly do not claim that it unblocks the artery but assert that it improves "the performance of heart". They have also discussed to a little extent their success story with lauki (bottle gourd) at HridayaMitra Mandal, an organisation based in Nagpur. The lay and the learned would, however, be more informed and illuminated in this regard if more scientific analyses are provided in the future. We must not fall into the old trap of the "naturalistic fallacy", thinking that something is acceptable only because it is natural, or that whatever is unnatural is undesirable.

We also feel that healthy and democratic discussions on the questions and assertions made by the authors should prevail in our academics and conferences, for we should not forget the famous words of Karl Popper that "Knowledge advances not by repeating known facts but by refuting false dogmas", naturalistic or reductionist.

\section{References}

1. Herrick JB. Landmark article (JAMA 1912). Clinical features of sudden obstruction of the coronary arteries.JAMA.1912 Dec 7[cited 2018 Jun 6]; LIX (23): 2015-2022. Available from: https://jamanetwork.com/journals/ jama/article-abstract/433082

2. Hurst JW. Obstruction of the coronary arteries. JAMA. 1983 Oct 7; 250(13):1763-65

3. McCormick J, Skrabanek P. Coronary heart disease is not preventable by population interventions. Lancet. 1988 Oct 8;332(8615):808-62.

4. Redberg RF. Overuse of percutaneous coronary interventions. Editor's Note. JAMA Intern Med. 2018;178(2):247. doi:10.1001/ jamainternmed.2017.7828

5. Krumholz HM. Cardiac procedures, outcomes, and accountability. N Engl J Med. 1997 May 22;336(21):1522-3.

6. Torrey EF. The Death of Psychiatry. New York: Penguin Books; 1975. 234 pp.

\title{
Love, remember and write against all odds
}

\section{ROHINI SHUKLA}

Gayathri Prabhu. If I had to tell it again. Noida, UP: HarperCollins Publishers; 2017. pp 192, INR 216 (Paperback), INR 99 (Kindle). P-ISBN: 978-93-5277-375-6

If I had to tell it again by Gayathri Prabhu is a dauntless memoir about a father-daughter relationship that is afflicted by mental illness. Set in the years between 1948 and 2014, the story moves in and out of Karnataka with Prabhu's survival endeavours, personal and professional. Along the way, the reader gets an intimate look into middle-class family life and a woman's struggle to become someone of her own in the face of paralysing circumstances - child sexual abuse, adolescence bereft of basic coping skills, divorce, a delicate bond with her father SGM Prabhu, two lost pregnancies, and a precarious career. All this is written about with a rare kind of sombre beauty. I was overwhelmed when I first read the book, but the second time around, after the initial deluge of emotions had passed, I realised why Krupa Ge says that "this book was necessary. An essential one. It had to be written." (1) The reasons, as is the case with an exceptional piece of literature, go

Author: Rohini Shukla (rohini.shukla@gmail.com), PhD Candidate Department of Religion, Columbia University, New York 10027 USA.

To cite: Shukla R. Love, remember and write against all odds. Indian J Med Ethics. 2018 Oct-Dec;3(4)NS:339-40. DOI:10.20529/IJME.2018.060.

Published online on July 30, 2018.

Manuscript Editor: Sanjay A Pai

CIndian Journal of Medical Ethics 2018 well beyond the inherent value of writing about stigmatised and misunderstood realities. If I had to tell it again pushes its reader to ask fundamental questions about parenting, how mentally ill individuals relate to each other and to the larger world, and the human ability to hurt, nurture, love and forgive.

In the initial pages of the book, one wonders if SGM's undiagnosed condition lives through Prabhu in the same debilitating form - alcoholism. There is a tense moment later in the narrative when Prabhu's biological impulse does push her in that direction. But by then, having aligned with multiple voices - Prabhu's retrospective voice, a reflexive third-person voice, a fictionalised character in a play, at times even SGM - the reader knows well that Prabhu's story does not collapse into SGM's. Their stories, like their lives and personalities, remain distinct. While SGM refuses to seek professional help, Prabhu painstakingly "called it whatever the doctor called it, went to therapy, took my medication, clawed my way out, inch by inch, over many years" (p 31). She confronts her clinical depression for what it is, against the pervasive rhetoric of mental illnesses being 'tendencies' with quick fixes - rhetoric that percolates deep into her family and immediate surroundings. And yet, it is difficult to read this confrontation as a valorisation of medical science, or as a valorisation of conscientious decisionmaking. This subtlety gives If I had to tell it again a rare humane edge. Through SGM's troubled and distant character, Prabhu addresses the question of how family life and socio-political cultures bleed into each other to sustain the lonesome mentally ill. 
Prabhu tells us early on that "It was around Hindutva politics that we had had our first real fight, over the whole Ayodhya agenda of the BJP... it drove him crazy that I did not see things his way" ( $p$ 29). What is his way of seeing things? Can it be reduced to his condition? SMG lived by a political-theology that synced with right-wing Hindutva politics. He had worked for the RSS and "the rhetoric of sacrifice and self-denial was our father's mainstay" ( $p$ 28). He firmly believed in fate, discipline through violence, philanthropy, raising daughters as sons, and the inherent goodness of man. He eschewed planning, saving money, being professional, and teaching through kindness; he was reckless (and justifiably so, according to him) on the road. His social circle bragged about his capacity to tolerate pain; they considered it courageous. "Everything appealed in its extremes" ( $p$ 80), including the Babri Masjid rampage because his "inherent sense of service could be clothed in the social comfort of Hindu pride and identity" (p 106). In a moment of brave declaration, Prabhu tells us that SGM "danced in front of the screen as frenzied mobs climbed the dome and chipped away at bronzed beautiful stone. I remember something inside me curdling slowly. You cheered the hooligans -- you wished you had been there!.... It was repulsive to me" ( $p$ 106). What Prabhu shares with SGM - mental illness, a passion for storytelling, love for dogs - runs deep, but what Prabhu refuses to share runs deeper in the narrative. Her refusal to inherit his way of seeing things defines the first irreversible chasm in their relationship.

This tension between inheritance, convention, and willful deviation becomes all the more poignant as Prabhu finds a career SGM does not envision for her. There is often a wide dissonance in what parents dream for their children, and what children dream for themselves, and this is true regardless of mental illness and conflicting politics. In this context, If I had to tell it again mindfully leads a much-needed dialogue about parenting - how do you teach mathematics if your child is not interested? What do you do if she is interested but unable to learn? How do you enable her to communicate her feelings, aspirations, and desires? How do you teach her to debate, disagree, question, refuse? How do you nurture a healthy imagination in children? How do you protect them and teach them to protect themselves? In other words, what is good parenting? "There was no awareness that children might end up feeling utterly undeserving if turned into monks who have to hone an ability to refuse, and that it leads to a murky adulthood of repeatedly saying no when one means yes to friends, lovers, authority figures, one's heart" ( $p$ 77) reading this much, I imagine, could be eye-opening for young parents who are stranded between learning from their own experiences and the lack of a satisfactory public debate on parenting in India.

Any retrospective account of a shared parent is complicated by the fact that the same events, especially traumatic ones, are remembered differently. Prabhu and her younger sister $G$ deal with the same parents, attend the same funeral, grow up listening to the same stories. $\mathrm{G}$ is Prabhu's rock solid support, but their life trajectories are different, as are their ways of remembering, grieving and coping. How then does one write a genre that audaciously claims 'this really happened'? Prabhu is careful to never present her truth as the truth, but in India, the stakes of writing a memoir are high not only because memory is partial. As Prabhu perceptively puts it, "And I know why there are such few memoirs being written in this country about the sort of suffering that only families can inflict and endure. The rhetoric of duty, sacrifice and family honor turns ceaselessly like a giant oil press" (pp 124-5). If I had to tell it again is a compassionately written contradiction because it is a memoir that goes beyond this rhetoric - a must-read because it embraces the need to be just to oneself when life is not kind.

\section{Reference}

1. Ge K. Gayathri Prabhu's If I Had To Tell It Again narrates a story of extraordinary suffering and love. Firstpost.com. 2018 Jan 7[cited 2018 Jul 10]. Available from: https://www.firstpost.com/living/gayathri-prabhusif-i-had-to-tell-it-again-narrates-a-story-of-extraordinary-sufferingand-love-4288753.html

\section{An editor speaks: Setting the record straight}

\section{SANJAY A PAI}

\section{Jerome $P$ Kassirer, Unanticipated outcomes: A medical memoir. Wellesley, MA; Jerome P Kassirer, 2017, pp x + 172, USD 35, Kindle Rs 449, ISBN 978-0-692-80871-9.}

\footnotetext{
Author: Sanjay A Pai (sanjayapai@gmail.com), Consultant Pathologist and Head of Pathology, Columbia Asia Referral Hospital, Malleswaram, Bengaluru 560055 , INDIA.

To cite: Pai SA. An editor speaks: Setting the record straight. Indian J Med Ethics. 2018 Oct-Dec;3(4)NS:340-2.DOI:10.20529/ IJME.2018.055.

Published online on July 13,2018.

OIndian Journal of Medical Ethics 2018
}

An opportunity to read the memoirs of one of the most famous medical editors of our times, of one of the most prestigious medical journals of all time, was not something I could pass up. Thus, it was with glee and curiosity that I took up the job of reading and reviewing the memoirs of Dr Jerome Kassirer, former editor-in-chief of the New England Journal of Medicine (NEJM).

Jerry Kassirer was editor of the journal from 1991 to 1999, and a considerable part of the book - and its raison d'etre - explores those eight years. However, it begins with a brief interesting history of the NEJM and is followed by the story 